\title{
Когнітивні операції ідентифікації імплікатів
}

\section{О. О. Гриняк}

Херсонський державний університет, м. Херсон.Україна

Corresponding author. E-mail olga.grinyak08@gmail.com

Paper received 15.01.19; Accepted for publication 20.01.19.

\section{https://doi.org/10.31174/SEND-Ph2019-189VII55-04}

\begin{abstract}
Анотація. У статті значна увага приділяється розмежуванню різних видів інформації, обумовлених тривимірною семантичною структурою тексту: змістово-фактуальною, змістово-концептуальною та підтекстовою, або імпліцитною. Новизною відзначається розроблена на основі положень когнітивної лінгвістики та ії̈ відгалуження - когнітивної поетики - комплексна методика інференційного аналізу імплікатів. Уперше визначено лінгвокогнітивні механізми формування імплікатів у поетичному тексті, виявлено низку когнітивних операцій, що забезпечують вилучення імплікатів на дотекстовому рівні. Поетичний текст характеризується різними площинами мовного вираження думки про світ: експліцитною, імпліцитною. Вилучення імпліцитних смислів передбачає когнітивну обробку тексту з урахуванням його передконцептуальної, концептуальної та вербальної іпостасей. У статті уперше дається картина імплікативного простору американської поезії модерну і постмодерну.
\end{abstract}

Ключові слова: імплікат, концепт, передкатегоризація, індикатор імплікату, імплікативний простір.

Вступ. Підгрунтям виникнення імплікату виступає архетип або концепт, який має словесне втілення у поетичному тексті. Визначення експліцитного й імпліцитного смислу поетичних форм відбувається шляхом передкатегоризації. Передкатегоризація як розумова діяльність базується на інтуїції та когнітивних операціях декодування емоціогенного передзнання, що активується архетипами, сигналами наявності яких виступають архетипні символи, вербалізовані в словесній тканині поетичного тексту [15, с. 19-21].

Для визначення й пояснення особливостей формування імплікативного простору нами сформульовано визначення, згідно з яким поетичний текст як багатовимірна структура є результатом інтеріоризації знань про певний фрагмент картини світу. Лінгвокогнітивний аналіз поетичного тексту спрямований на розкриття дотекстової, текстової, позатекстової інформації, закодованої у семантиці його одиниць, мовне вираження яких має експліцитний та імпліцитний характер. Імпліцитна інформація формує імплікативний простір поетичного тексту, що є системою взаємопов'язаних імплікатів. Виокремлення імплікатів як компонентів імплікативного простору здійснюється шляхом когнітивної обробки різних видів інформації, закодованої у поетичних текстах.

Короткий огляд публікацій по темі. Проблема імпліцитності привертає увагу не тільки лінгвістів, а й літературознавців, філософів, психологів, логіків, соціологів. Із розвитком когнітивного підходу, який базується на інтеграції знань із психології, філософії, культурології, антропології і лінгвістики, почався пошук нових шляхів до розкриття специфіки використання і функціонування мовних одиниць 3 неявно вираженим смислом [2], механізмів кореляції імплікаційно-експлікаційних зв'язків у семантиці художнього тексту [10], засобів вербалізації інтендованих імпліцитних смислів [15], факторів, які призводять до активації прихованого потенціалу смислу [6].

Метою дослідження $\epsilon$ реконструкція імплікативного простору сучасної американської поезії шляхом визначення лінгвокогнітивних механізмів формування його складників.

Матеріалом дослідження є 3153 текстові фрагменти, що містять індикатори імплікатів, із 1254 різних за обсягом поетичних текстів, що сукупно становлять
2738 сторінки. Це - поетичні тексти американських поетів XX століття: Е. Паунда, Р. Фроста, У. Стівенса, У. Уільямса, К. Сендберга, Р. Джефферса, Е.А. Робінсона, Г. Снайдера, Г. Корсо, А. Гінзберга, Р. Блая та інших.

У дослідженні застосовано комплексну методику аналізу поетичних текстів, що включає низку методів: компонентного аналізу для визначення семантичної структури номінативних одиниць, які входять до складу індикаторів імплікатів; контекстуального аналізу для встановлення способів реалізації індикаторів імплікатів в межах мікро- або макроконтексту; виявлення механізмів формування індикаторів імплікатів здійснено методом інтерпретаційнотекстового аналізу з використанням лінгвостилістичного аналізу тропів і фігур; концептуального аналізу спрямованого на дослідження природи індикаторів імплікатів шляхом з'ясування лінгвокогнітивних операцій і процедур, задіяних у їх формуванні; на основі кількісного аналізу визначено домінанті імплікати, інференційний аналіз семантики поетичного тексту застосовано для виявлення імплікатів на різних його рівнях.

Результати дослідження. Для ідентифікації імпліцитного смислу в поетичному тексті необхідно визначити, яким чином найрізноманітніші мовномовленнєві форми, за допомогою яких автор відтворює багатство навколишнього світу, викликають у свідомості читача/інтерпретатора певні ментальні репрезентації мовного знання, як це знання здобувається та формується у свідомості [5, с. 120].

Виявлення імплікатів на дотекстовому рівні включає такі когнітивні операції і процедури:

- розпізнання імплікату за архетипними символами;

-реконструкцію архетипної/концептуальної образсхеми як передконцептуальної іпостасі образу [2, с. 236] $з$ метою виявлення концептуальних імплікацій, які складають зміст архетипу. Моделювання образсхеми базується на інформації з енциклопедичних і лінгвістичних джерел;

- трансформацію образ-схеми, яка складає узагальнений зміст словесного поетичного образу, за допомогою лінгвокогнітивних операцій мапування [11] та основних лінгвокогнітивних процедур компресії, 
комбінації й інтертекстуалізації [16].

Наприклад: «The green bug sleeps in the white lily ear./The red bug sleeps in the white magnolia./Shiny wing, you are choosers of color./You have taken your summer bungalows wisely» [14, p.344]. Наведений імажиністський вірш в імпресіоністській манері змальовує кружляння жуків, зеленого і червоного, над білими квітами. Узагальнений смисл тексту виявляється шляхом реконструкції концептуальної метафори ПРИРОДА Є МУДРІСТЬ, яка лежить в основі поетичного тексту. Виникає питання, чому вважається, що вибір зроблено мудро (wisely). Відповідь криється в імплікатах, представлених архетипними колоративними символами green - молодий, сповнений бажань, та red - зрілий, енергійний, досвідчений [8]. Молодий (зелений) жук обирає лілію, форма якої може слугувати захистом від небезпеки. До того ж лілія - символ чистого, юнацького кохання. Натомість червоний жук - зрілий, упевнений у собі - оселяється в магнолії, яка вважається квіткою зрілого кохання, поваги і самоствердження [7, с.313].

Архетип активується стилістично маркованими компонентами словесних поетичних образів, що $\epsilon$ індикаторами імплікатів. 3 метою визначення актуалізованого в поетичному тексті компоненту архетипу, тобто концептуальної імплікації, необхідно декодувати семантичну структуру індикатора, за допомогою звернення до енциклопедичних словників, наукових довідників, що містять інформацію про архетипи. Кожен архетип містить декілька концептуальних імплікацій. Усі архетипи амбівалентні [9, с.123], тобто містять у собі різні значення. Так, наприклад, закладена в архетипі ВОДА енантіосемія як протиріччя різних значень одного багатозначного слова пояснює наявність у художній свідомості протилежних понять - жива та мертва вода, вода - джерело життя та погибелі (Всесвітня Повінь) [2, с.229]. У поетичному тексті об'єктивується одна чи декілька концептуальних імплікацій залежно від змісту словесного поетичного образу. Узагальнений зміст словесного поетичного образу - це зміст, виявлений через аналіз лінгвокогнітивних операцій мапування, що дозволяють креслити спосіб мислення та виокремити компонент словесного поетичного образу, який містить імплікат.

Так, наприклад, індикатори імплікату невпинність часу: «time», «young man», «life» і «clocks» ідентифікуються у словесному поетичному образі: «Time is a young man with ballplayer legs, time runs a winning race against life and the clocks» [14, p.197]. Сприйняття та експлікація смислу уповільнюється внаслідок нетипового порівняння «часу» $\mathrm{i}$ «молодого чоловіка з ногами футболіста». Розкриття прихованого смислу стає можливим за умови виявлення механізмів творення поетичної форми. Метафоричне осмислення «time» в термінах «ballplayer legs», «winning race» є результатом аналового мапування. За допомогою лінгвокогнітивної процедури узагальнення ознак сутностей царини мети: time - life, clocks, та області джерела: ballplayer - a man who moves quickly with a ball, race - a competition between people, animals, cars etc to see which is the fastest [13, p. 43, 507], виявляємо концептуальну метафору ЧАС $€$ РУХ. Осмислення концепту ЧАС в термінах концепту РУХ є можливим завдяки наявності онтологічних відповідностей (споріднених якостей та ознак, що іманентно притаманні порівнюваним сутностям), які містяться у концептах і які можна проектувати з однієї області знань на іншу [11, c. 211]. Концептуальна схема ЧАС Є РУХ дозволяє розкрити імпліцитну сторону смислу - час не зупинити.

Усталена метафора «time runs» набуває нового, конкретизованого осмислення із-за протиставлення «time runs a winning race against life and the clocks»«час є сильнішим за життя і хронометри». Результатом лінгвокогнітивної операції контрастивного мапування - проектування онтологічних властивостей однієї сутності на протилежні онтологічні властивості іншої сутності $-\epsilon$ породження прихованого смислу. Спорідненими онтологічними властивостями складників антитези є риси концепту ЧАС. На периферії семантичного поля даного концепту проектуються антонімічні значення сутностей безмежність і вимірність. Таким чином унаслідок зіткнення двох протилежних якостей концепту ЧАС, вербалізовантих в індикаторах «time», «winning race», «life», «clocks» простежується закладений в поетичному тексті імпліцитний смисл: непідвладна людині сила часу. В іншому контексті індикатори «time», «young man», «life» i «clocks» втрачають свої імпліцитні властивості: «What time is it? The young man is smart. Is there life on the other planets? All the clocks in the house stroke 12» [8].

3 метою пояснення методики ідентифікації імплікату npiopumem проаналізуємо словесний поетичний образ: «The wings and the wild hungers, the wave-worn skerries,/ the bright quick minnows/Living in terror to die in torment» [12, p.1251] (Крилаті, й голодні звірюги, $i$ хвилями стерті стрімчаки,/ яскраві, блискучі рибин-

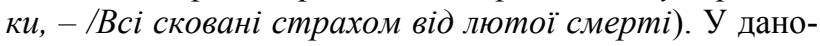
му контексті номінативна одиниця «the wings» (крила) вживається замість слова «birds» (nтахи), перенесення назви відбувається за наявності відношень частина-ціле. Формування індикаторів імплікатів, що містять метонімію, відбувається за допомогою субститутивного мапування. Субститутивне мапування на відміну від аналогового, базується на асоціативному поетичному мисленні, суть якого полягає в проектуванні мисленнєвих зв'язків імплікаційного характеру на семантичне варіювання мовних одиниць [4, с.251]. Імплікація, за словами М.В. Нікітіна, є мисленнєвою операцією встановлення лінійної залежності між концептами у свідомості як відбиття реальних (а іноді й уявних) зв'язків між реальними (а іноді й уявними) сутностями реального (а іноді й уявного) світу [там само]. Сукупність цих імплікацій створює імплікаційні структури свідомості, які є мисленнєвим аналогом будови світу, відбиття реальних й уявних зв'язків між предметами, між їх ознаками, між частиною і цілим, між причиною і наслідком, між діяльністю та іiі результатами [3, с.41-42]. Таким чином, субститутивне мапування - це операція ідентифікації імплікативних зв'язків між варіантами референтів концепту царини та проектування їх на іншу сутність цієї ж царини словесного поетичного образу шляхом лінгвокогнітивної операції заміщення. Дана процедура полягає у відшукуванні серед спектру референційних значень концепту таких, що можуть заміщувати одне одного [там само]. 
Отже, номінативна одиниця «the wings» ідентифікується як індикатор, оскільки в основі має концепт ПРИРОДА, який містить ряд референційних значень, втілених у наведеному слові, та позначає представників вищого класу тваринного світу. Номінативна одиниця «the wings» виступає індикатором імплікату npiopumem за умови контактного розташування 3 номінативною одиницею «тіппоws» (мілка рибина, дрібнота) та метонімічно вказує на ієрархічні відносини як між представниками тваринного світу, так і різних класів суспільства. Вищі класи мають пріоритет, тому що наділені тими засобами («the wings»), які дозволяють піднятися над усіма іншими (minnows).

У свою чергу, основане на метонімії словосполучення «wild hungers» виступає індикатором імплікату стимул. У ньому позначений основний імпульс жагу, голод, нестримне бажання, що слугує стимулом для здобуття сил необхідних у боротьбі за виживання.

У поетичному тексті Е.A. Робінсона «Еros Turannos» імплікат уведення в оману виявляємо за допомогою ідентифікації його індикатору словосполучення «blurred sagacity», у контексті словесного поетичного образу: «Between a blurred sagacity/ That once had power to sound him,/ And Love, that will not let him be/ The Judas that she found him» [1, p.186].

Техніка ідентифікації індикатору імплікату полягає, по-перше, у сприйнятті вербального сигналу «blurred sagacity», який в результаті нестандартного подання зображуваного предмету уповільнює когнітивний процес обробки інформації. По-друге, ця техніка базується на розкритті механізму творення поетичної форми, яка, крім експліцитного «кохання не дозволяло розгледіти в ньому Іуду», містить імпліцитний смисл уведення в оману. У вищенаведеному словесному поетичному образі, який містить оксиморон, простежується контрастивне мапування. В основі контрастивного мапування лежить парадоксальне поетичне мислення, що обумовлює появу словесних поетичних образів із експліцитним та імпліцитним смислами.

По-третє, техніка ідентифікації індикатору імплікату спирається на визначення концепту як основи для розпізнання наявності в індикаторі прихованого смислу. Спорідненими онтологічними властивостями складників оксиморону «blurred sagacity» $є$ риси концепту СПРИЙНЯТТЯ. На периферії семантичного поля цього концепту проектуються антонімічні значення сутностей проникливість і недалекозорість. Унаслідок зіткнення двох протилежних якостей концепту СПРИЙНЯТТЯ, а саме АДЕКВАТНЕ СПРИЙНЯТТЯ і НЕАДЕКВАТНЕ СПРИЙНЯТТЯ, простежується закладений у поетичній формі імпліцитний смисл: закохана людина необ'єктивно оцінюе свого обранця.

Як зазначає Л.І. Бєлєхова, в американській поезії XX століття, а саме у модерністському і постмодерністському напрямах, поетичні образи, в основі яких лежить оксиморон, зазнають змін через реорганізацію синтаксичної структури. Унаслідок вживання прийменників між номінативними одиницями, які зштовхуються, відбувається семантичне узгодження, пом'якшення, нівелювання протиріччя між компонентами образу, що пояснюється особливостями парадоксального поетичного мислення в поезії модерну і постмодерну [3, с. 53]. Це призводить до ускладнення ідентифікації індикаторів імплікатів та декодування прихованих в образі смислів.

Прискорення темпу життя у другій половині XX на початку XXI століття не залишає часу помічати разючі контрасти оточуючої дійсності, однак ці моменти все одно знаходять своє відображення у поетичних текстах модерністського спрямування. Наприклад, індикаторами імплікату «привабливість повноцінного існування» виступають номінативні одиниці: «beauty» «terrible», «faces», «nonentities», що входять до складу словесного поетичного образу: "Why do I write today?/ The beauty of the terrible faces/ of our nonentities/ stirs me to it...» [1, p.244] (Що змушує мене писати сьогодні?/ Краса жахливих облич/ наших нікому не потрібних людей/ змушує мене...). Протилежні ознаки царини джерела, що є складниками концепту ЯКІСТЬ, зіштовхуються. На периферії семантичного поля даного концепту відбувається мапування аксіологічних значень сутностей краса і потворність. Подвійне протиставлення: «краса» (the beauty) - «потворність» (the terrible faces) та «буття» (faces) - «небуття» (nonentities) слугує основою для створення ефекту «очуднення». Процес декодування уповільнюється, що вказує на наявність у словесному поетичному образі імплікату. ПОЗИТИВНА ЯКІСТЬ зіштовхується 3 НЕГАТИВНОЮ ЯКІСТЮ, НАПОВНЕНІСТЬ з ПУСТОТОЮ, в результаті чого простежується витіснення імпліцитного смислу: краса жсиття в його внутрішній $\boldsymbol{i}$ зовнішній наповненості.

Отже, необхідною умовою ідентифікації індикаторів імплікатів $є$ не тільки сприйняття «очудненого» вербального сигналу, який уповільнює когнітивний процес обробки інформації, а й розкриття механізмів утворення поетичної форми, яка крім експліцитного, містить імпліцитний смисл, з метою визначення архетипної/концептуальної схеми, необхідної для розпізнання імплікату.

Складовою частиною структури будь-якого концепту й архетипу виступає концептуальна імплікація, передзнання, що дані людині від початку [2, с.149$157,237]$. У рамках нашого дослідження під концептуальною імплікацією розуміємо сукупність стереотипних асоціацій, закріплених у розумовій системі людини на основі мовленнєвого, а також когнітивного досвіду. Процес виникнення імплікату можна представити у вигляді наступного ланцюга: архетип/концепт - концептуальна імплікація - імплікат. Послідовність лінгвокогнітивних операцій, спрямованих на виявлення імплікатів, грунтується на стереотипних асоціаціях, які активуються у свідомості при сприйнятті словесних поетичних образів, наділених не тільки експліцитним, але й імпліцитним смислом.

3 метою ілюстрації вищесказаного пропонуємо розглянути наступний приклад. Імплікат швидкоплинність життя виявляємо за допомогою ідентифікації його індикаторів «live», «rain», «snow», «wet», які в контексті вірша У. Стівенса «Sunday Morning» набувають імпліцитних властивостей:

Divinity must live within herself:

Passions of rain, or moods in falling snow;

Grievings in loneliness, or unsubdued

Elations when the forest blooms; gusty

Emotions on wet roads on autumn nights; 


\section{All pleasures and all pains, remembering}

The bough of summer and the winter branch,

These are the measures destined for her soul [17].

Формування вищенаведного словесного поетичного образу, який окрім експліцитного «опис природних явищ» містить імпліцитний смисл, є результатом аналового мапування структур знань з царини джерела: rain (the water that falls from the sky), snow (small, soft, white pieces of frozen water that fall from the sky in cold weather [13, p.592]), wet (covered with liquid, especially water [там само, p.698] - на аналогічні структури знання царини мети: live (having life [там само, p.370]). Звідси випливає, що підгрунтям цього словесного поетичного образу виступає концептуальна метафора ЖИТТЯ С ВОДА. Зміна стану води у контексті даного поетичного тексту імпліцитно вказує на зміни у житті. Для виявлення прихованого смислу застосовуємо низку когнітивних операцій: ідентифікація архетипних символів, реконструкція образ-схем, які можна представити у вигляді такого ланцюга: індикатори, що містить архетипи ЖИТТЯ і ВОДА - концептуальні імплікації плинність, мінливість, динамізм - імплікат швидкоплинність життя.

Індикаторами імплікату швидкоплинність жит$\boldsymbol{m} \boldsymbol{я}$ виступають також номінативні одиниці та словосполучення, які позначають пори року: «when the forest blooms», «autumn», «summer», «winter». Словосполучення «when the forest blooms» імпліцитно вказує на ту пору року, якій з урахуванням особливостей помірного клімату відповідає весна. Передкатегоріальною основою вищенаведеного індикатору $є$ архетип РЕГЕНЕРАЦІЯ, концептуальною імплікацією даного архетипу є циклічність [20 Бєлєхова 2004, с.234]. Отже, на основі концептуальних імплікацій архетипів ЖИТТЯ, ВОДА і РЕГЕНЕРАЦІЯ активується імплікат швидкоплинність життя. У такий спосіб доходимо висновку, що концептуальна імплікація відіграє ключову роль у виникненні імплікатів.

Основою словесного поетичного образу, компоненти якого містять прихований смисл: «Time runs with an ax and hammer/, time slides down the hallways with a pass-key and a master-key/ and time gets by, time wins» [Sandburg], є базова концептуальна схема ЧАС $€$ РУЙНІВНИК. Вона є результатом процедури узагальнення ознак сутностей царини мети time, та області джерела ax, hammer, pass-key, master-key - means for destruction (засоби для злому). Ця концептуальна схема - наслідок використання загальнолюдських знань про концепт часу, який випробовує пам'ять, речі, споруди на міцність. Концептуальна імплікація концепту ЧАС є зміна, рух, концепту РУЙНІВНИК - cmpax, руйнування. Отже, із застосуванням вищенаведених операцій виокремлюємо індикатори, які вербалізують концепти ЧАС, РУЙНІВНИК - концептуальні імплікації зміна, рух, страх, руйнування - виявляємо імплікат нищівна сила часу.

У поетичному тексті У. Стівенса «The Poems of Our Climate» індикаторами виступають компоненти наступних словесних поетичних образів: «The imperfect is our paradise» (Недосконалість - наша благодать), «Note that, in this bitterness, delight» (Поглянь, y иіій гіркоті - насолода) [19 Л.інтер.,с.68-69]. Підгрунтям словесних поетичних образів «The imperfect is our paradise» та «in this bitterness, delight» $є$ концептуальний оксиморон. Концепт ДОВЕРШЕНІСТЬ зіштовхується із концептом НЕДОСКОНАЛІСТЬ, ПОЗИТИВНА ЕМОЦІЯ з НЕГАТИВНОЮ. Ці концепти містять спільну концептуальну імплікацію мінливість, яка дозволяє виявити наступні імплікати: досконалість немас межс, прагнення ідеалу, насолоди.

Таким чином, за допомогою інференції як комплексу лінгвокогнітивних операцій поетапно виявляємо імплікати. Їх індикатори, компоненти словесних поетичних образів, які окрім експліцитного, наділені імпліцитним смислом, дозволяють визначити роль і місце імплікату в імплікативному просторі поетичного тексту.

Висновки. Дослідження передкатегоріальної сторони імплікативного простору уможливило розкриття механізмів формування його складників, що полягає у розпізнанні архетипу або концепту, який лежить в основі індикатору імплікату; виявленні образ-схем, що слугують підгрунтям словесних поетичних образів, які містять індикатори імплікату; визначенні виду мапування, результатом дії якого є виникнення словесного поетичного образу, компоненти якого вербалізують імплікат.

Проведений лінгвокогнітивний аналіз архетипів на дотекстовому рівні поетичного тексту дозволив виявити їхні образ-схем, до структури яких входять концептуальні імплікації. Концептуальні імплікації, відчуття та уявлення, оброблені за допомогою усвідомлених когнітивних операцій, є ключовими у вилученні прихованого смислу.

Визначено послідовність операцій ідентифікації імплікатів на дотекстовому рівні. Першим етапом ідентифікації імплікату $є$ сприйняття вербального сигналу, який уповільнює когнітивний процес обробки інформації. Другим - розкриття механізмів творення поетичної форми, яка, крім експліцитного, містить імпліцитний смисл. Третім - визначення архетипної/концептуальної схеми як основи розпізнання імпліцитного смислу поетичної форми.

Упорядкування імплікатів в єдине змістове ціле дало змогу дослідити імплікативний простір як окремого поетичного тексту, так і низки поетичних текстів одного або декількох авторів. Кількісний аналіз імплікатів на дотекстовому рівні засвідчив, що імплікативний простір поетичних текстів епохи модерну структурно відрізняється від імплікативного простору постмодерністських віршів. У імплікативному просторі модерністських віршів переважають відношення смислової подібності та смислового протиставлення між імплікатами, що $є$ наслідком переосмислення усталених понять та істин. У поезії постмодернізму кількість відношень смислового включення є більшою, це вказує на деталізацію відображеної у поетичних текстах реальності.

ЛІТЕРАТУРА

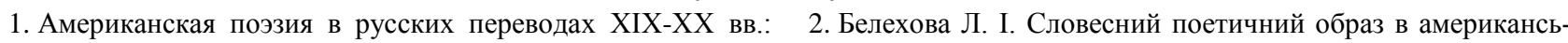
[сост. С. Б. Джимбинов]. М.: Радуга, 1983. 667c.

кій поезії: лінгвокогнітивний погляд: [монографія] Херсон: Айлант, 2004. 376c. 
3. Белехова Л. І. Різноаспектне дослідження поетичного мовлення. Збірник наук праць. Херсон: Айлант, 2018. $183 \mathrm{c}$.

4. Никитин М.В.Курс лингвистической семантики. М.: Научный центр проблем диалога, 1996. 760 с.

5. Никонова В. Г. Жанр - текст - художественный концепт (опыт семантико-когнитивного анализа) // Реальность, язык и сознание - Тамбов: Изд-во Тамбовск. гос. ун-та имени Г.Р.Державина, 2005. III. С. 159-165.

6. Потебня А. А. Теоретическая поэтика. М.: Высшая школа, 1990. $331 \mathrm{c}$.

7. Символы, знаки, эмблемы: энциклопедия [авт.-сост. В.Э.Багдасарян, И.Б.Орлов, В.Л.Телицын]. М.: ЛокидПресc, 2003. 495 c.

8. Словарь английского языка ABBYY Lingvo - URL: http://lingvo.yandex.ru/en?text=FLY\&st_translate $=1 \&$ lang=e $\mathrm{n} \& \mathrm{dAB}=\mathrm{on}$

9. Юнг К.-Г. Психологія та поезія // Слово. Знак. Дискурс: Антологія світової літературно-критичної думки ХХ ст. Львів: Літопис, 2001. С. 119-138.

10. Freeman M. Metaphor and metonymy as conceptual mappings. 6-th International Cognitive Linguistics
Conference Stockholm: Stockholm University Press, 1999. P. 58-59.

11. Lakoff G. Philosophy in the Flesh: The Embodied Mind and its Challenge to Western Thought // G. Lakoff, M. Johnson. N.Y.: Basic Books, 1999. 624 p.

12. Norton Anthology of American Literature / Ed. by N.Baym, R.Gottesman, L.B.Holland and others. - N.Y., L.: W.W. Norton \& Company, 1989. 2856 p.

13. Oxford Wordpower Dictionary. N.Y.; Oxford Univ. Press, 1994. $746 \mathrm{p}$.

14. Sandburg, C. The Complete Poems. - San-Diego; N.Y.; L.: Harcourt Brace Jovanovich Publishers, 1970. 797 p.

15. Tsur, R. Toward a Theory of Cognitive Poetics. Amsterdam: Elsevier Science Publishers, 1992. 549 p.

16. Turner M. The Literary Mind: The Origin of Thought and Language. N. Y.; Oxford: Oxford University Press, 1998. 187 p.

17. Stevens, W. The Poems of Our Climate. - URL: http://thepoemoftheweek.blogspot.com/2006/06/poem-ofweek-6192006-poems-of-our.html
1. merican poetry in Russian translations [ed. S.B. Djambinov] M.:Raduga, 1983. 667p.

2. Belehova, L.I. Verbal poetic images of American poetry: linguistic and cognitive aspects: [monograph]. Kherson: Ailant, 2004. $376 \mathrm{p}$.

3. Belehova, L.I. Multiaspect investigation of poetic language. The collection of scientific works. Kherson: Ailant, 2018. 183 p.

4. Nikitin M.V. Course of linguistic semantics. M.: Scientific center of dialogue problem, $1996.760 \mathrm{p}$.

5. Nikonova V.G. Genre - text - fiction concept (semanticocognitive analyses) // Reality, language and consciousness Tambov: Tambov State University named by G.R. Derzhavin Publishing, 2005. III, P. 159-165.

6. Potebnya A.A. Theoretical Poetics. M.: Vishaya Skola, 1990. $331 \mathrm{p}$.

7. Symbols, signs, emblems: encyclopedia [ed. V.E. Bagdosaryan, I.B. Orlov, V.L. Telitsin]. M.: LocidOPress, 2003. 495 p.

8. English language dictionary ABBYY Lingvo - URL: http://lingvo.yandex.ru/en?text=FLY\&st_translate $=1 \& l a n g=e$ $n \& d A B=o n$

9. Yung C.-G. Psychology and poetry // Word. Sign. Discourse: Anthology of world literary and critical thought of XX century, 2001. P. 119-138.

\section{Cognitive operations of the identification of implicates}

\section{O. A. Grinyak}

Abstract. The article describes and analyses the principal ways of the distinction of different types of information caused by the three dimension semantic structure of the text: context factual, context conceptual, and implicit. The new and actual is the complex method of inferential analyses of implicates based on the principles of cognitive linguistics and its branch cognitive poetics. Linguistic and cognitive mechanisms of the formation of implicates in poetic texts are described for the first time, the chain of cognitive operations necessary to single out implicates on the pre-textual level is logically singled out. It is mentioned that a poetic text has double phenomena: explicit and implicit. To single out implicit senses it is obligatory to make linguistic and cognitive analyses of the text dealing with its pre-conceptual, conceptual and verbal hypostases. The actual is also the description of the implicative space of modern and postmodern poetry.

Keywords: implicate, concept, pre-categorization, indicator of implicate, implicative space. 